\title{
GIS and RS Based Soil Erosion Modelling in Sri Lanka: A Review
}

\author{
I.D.U.H. Piyathilake ${ }^{1^{*}}$, E.P.N. Udayakumara ${ }^{2}$ and Sunethra Kanthi Gunatilake ${ }^{2}$
}

Date Received: $5^{\text {th }}$ June 2019 / Date Accepted: $21^{\text {st }}$ September 2020

\begin{abstract}
Purpose : Over the seventy years, various soil erosion modeling methods were developed in the world with different input requirements and complexity. Some of these soil erosion models have been applied in Sri Lanka covering several regions of the country at different scenarios over the past twenty years. Thus, the prime objective of this study is to compare commonly practiced GIS/ RS based soil erosion assessment models and derivation techniques of model parameters used in Sri Lanka.
\end{abstract}

Research Method: Scholarly research articles, conference proceeding papers, and previously published literature on GIS/ RS based soil erosion models over the past twenty years were critically reviewed, examined, and compared to find various methodologies in the derivation of soil erosion model parameters, analysis methods, and applications with special reference to Sri Lanka.

Findings : The results revealed that, in each case, the empirical soil erosion models have been applied to predict soil erosion rates in terms of rill and sheet erosion excluding gully erosion. Furthermore, soil loss at the catchment or entire country scale has been assessed in each case by using different derivation methods. The assessed soil erosion model parameters are $R$ factor (rainfall erosivity), $K$ factor (soil erodibility), $L S$ factor (slope gradient), $C$ factor (crop management factor), and $P$ factor (support practice factor).

Originality/Value : Different derivation methods of soil erosion model parameters ( $R, K, L S, C$, and $P$ ) were critically evaluated in order to find the most appropriate methods that can be applied in Sri Lanka in future research studies.

Keywords: GIS, InVEST-SR/SDR, Remote sensing, RUSLE, Soil erosion models, USLE

\section{INTRODUCTION}

Soil erosion can be simply defined as a naturally occurring process of the removal and transportation of topsoil due to erosive agents viz. water, wind, and gravity (Gunawan et al., 2013) while the soil erosion has been accelerated by human-induced activities viz. intensive agricultural practices, urbanization, and improper land management practices (Hewawasam, 2010; Udayakumara et al., 2010; Udayakuamara and Gunawardena, 2016). This soil erosion process consists of three steps as soil loosening, transport, and deposition (FAO, 2015) and in the phenomenon of soil erosion, individual soil particles are removed and transported from its original place to downstream by detaching from the topsoil layer. As the ultimate result of this process, the rich nutrient and carbon-containing topsoil are transported into drainage channels and eroded materials are accumulated in drainage channels (Shi et al., 2012; Issaka and Ashraf, 2017). These undesirable consequences of soil erosion lead to degrading agricultural lands and natural environments rapidly (Shougang and Ruishe, 2014). Thus, soil erosion is listed and classified as a severe environmental issue that

\footnotetext{
Faculty of Graduate Studies, Sabaragamuwa University of Sri Lanka, P.O. Box 02, Belihiloya, Sri Lanka.

iduhasantha@gmail.com

2 Department of Natural Resources, Faculty of Applied Sciences, Sabaragamuwa University of Sri Lanka, P.O. Box 02, Belihuloya, Sri Lanka.
}

iD http://orcid.org/0000-0003-0990-3276 
the world is facing (Panditharathne et al., 2019). As explained by Castro Filho et al. (2001), loss of soil due to erosion is found to be the main causative factor of land degradation in the world while $85 \%$ of land degradation is occurred due to the erosion process which reduced arable lands up to $17 \%$ (Singh and Panda, 2017; Wijesundara et al., 2018). This results in increasing the expenses for fertilizers and ultimately lands are abandoned (Singh and Panda, 2017) due to nutrient loss of arable lands, increasing the runoff by exposed impermeable soil and reducing the retained water availability (Ganasri and Ramesh, 2016). Moreover, Soil erosion paves the way to loss of esthetic values of the natural environment (Panditharathne et al., 2019) and habitat losses take place due to soil erosion while habitat loss is considered as one of the most prominent causes of biodiversity degradation (Dissanayake et al., 2019). Furthermore, as explained by Jayasekara and Kadupitiya (2018), due to the existence of long term soil erosion in drainage basins, the water storage capacity of reservoirs also gets reduced due to the delivery of sediments into reservoirs. Thus, it is clear that soil erosion has not only caused environmental and agricultural related problems but also negatively affected the global socio-economic and global sustainable development (Udayakumara et al., 2012; Han et al., 2016).

According to the previous scientific findings, major regulatory factors of soil erosion have been experimentally identified as $\mathrm{R}$ factor, $\mathrm{K}$ factor, LS factor, C factor, and P factor (Smith, 1999). Out of these major driving factors of soil erosion, Phai et al. (2007) has scientifically proven that the most significant factor that contributes to soil erosion is the $\mathrm{R}$ factor. Nonetheless, soil erosion is a natural phenomenon, this process has been hastened by anthropogenic activities viz. intensive agriculture, using steep slopes for agricultural activities, improper land management practices, and deforestation (Wickramasinghe, 1988; Nayakekorala, 1998; Wijesekera and Chandrasena, 2001; Jayarathne et al., 2010). Furthermore, clearance of primary forest cover, mining, urbanization, and improper construction activities are major human-based causative practices that accelerate the natural soil erosion rates (Pimentel et al., 1987; Udayakumara et al., 2012; Diyabalanage et al., 2017; Cheng et al., 2018). In Sri Lankan highlands, it has been quantified that the natural erosion rate has increased by a factor of up 100 due to these human-based activities (Hewawasam et al., 2003; Hewawasam, 2010). Thus, before going to soil conservation strategies, accurate and timely evaluation and assessment of soil erosion rates should be carried out referring to the acceptable/ permissible soil loss tolerance limits (T values). $\mathrm{T}$ value denotes the amount of soil loss that is less than or equal to the rate of formation of soil and it is a basis for judging whether the soil has a potential risk of erosion (Li et al., 2009). Also, it is necessary to have knowledge of terrain, cropping system, and soil management practices (Jahun et al., 2015). Because of that, researchers from all around the world have been carrying out soil erosion related research studies to understand the mechanisms and rates of soil erosion (Onyando et al., 2005; Bhattarai and Dutta, 2007; Jaramillo, 2007; Anejionu et al., 2013; Gunawan et al., 2013; Balasubramani et al., 2015; Biswas and Pani, 2015; Devatha et al., 2015; Ganasri and Ramesh, 2016; Wijesundara et al., 2018; Dias et al., 2019; Fayas et al., 2019).

As explained by Zachar (2008), the soil erosion rates can be determined either by conventional field-based direct methods (using leveling, volumetric, pedological, morphometric, photogrammetric, and vegetation techniques) or indirectly by analyzing the constituents of removed soil viz. deluates, deflates, etc. When compared with conventional soil erosion assessing methods, soil erosion modeling is the most convenient and reliable tool for soil erosion assessments that permits the suitable selection of soil erosion control measures (Moehansyah et al., 2004). One of the main reasons for soil erosion modeling as so widely used throughout the world is certainly its high degree of flexibility and data accessibility, a parsimonious parameterization, extensive scientific literature, and comparability of results allowing to adapt the model to nearly every kind of conditions and regions (Allewel et al., 2019). Concentrating on the most broadly applied soil erosion models, Universal Soil Loss Equation (USLE) and its derivative models are the most prominent soil erosion models that have been applied all over the world in different 
scenarios (Igwe et al., 2017). In Sri Lanka, several research studies have been carried out in order to predict the soil erosion rates based on GIS and RS modeling and shown that soil erosion has emerged as one of the most severe environmental issues in Sri Lankan highlands (Wickramasinghe 1988; Nayakekorala 1998; Wijesekera and Chandrasena 2001; Wijesekera and Samarakoon, 2001; Hewawasam et al., 2003; Jayarathne et al., 2010; Hewawasam, 2010).

Moreover, in Sri Lanka, the previous researchers have used various derivation techniques for model parameters of USLE (Universal Soil Loss Equation), RUSLE (Revised Universal Soil Loss Equation), and InVEST-SR/SDR (Integrated Valuation of Ecosystem Services and Tradeoffs - Sediment Retention/ Sediment Delivery Ratio) model. Thus, the prime objective of this study is to compare commonly practiced GIS/ RS based soil erosion assessment models and derivation techniques of model parameters used in Sri Lanka.

\section{Introduction to Soil Erosion Models}

The assessment and prediction of soil erosion have been a challenge for a long time (Udayakumara, 2010) due to the fact that field-based conventional soil erosion assessing methods are labour intensive and time-consuming (Devatha et al., 2015). Thus, several soil erosion models have been developed since the 1930s (Lal, 2001; Laflen and Flanagan, 2013) that can be classified into empirical models, physically-based models, and conceptual models (Devatha et al., 2015). Presently, the USLE by Wischmeier and Smith (1965), and the RUSLE by Renard et al. (1991) are the most widely used soil erosion models. Soil erosion modeling guides comprehensive control of the soil erosion process by estimating soil erosion rates and sediment yields quantitatively and consistently (Igwe et al., 2017). The application of such soil erosion models mainly relies on climate variability, soil variability, landuse type, topography, and land management (C and $\mathrm{P}$ factors) of the study area, and those wide ranges of soil erosion models vary in their data requirement, complexity, and validation methods (Merritt et al., 2003; Anejionu et al., 2013). Soil erosion modeling plays an important role in estimating potential soil loss, sediment export, and sediment retention and future scenario analysis of various types of land use classes in order to plan future land management strategies and to monitor government policies on land management practices (Smith, 1999). All the developed soil erosion modeling techniques have been categorized into three model classes as empirical models, conceptual models, and physically-based erosion models (Devatha et al., 2015). Out of those three model classes, Empirical models are mathematically and practically the simplest models that can be applied in conditions with limited data availability (Igwe et al., 2017). Empirical models have limitations of applicability to regions and ecological conditions other than from which data were used in their development (Merritt et al., 2003). According to Smith (1999), the disadvantages of Empirical models are that they: (1) are based on a statistical analysis of important factors in the soil erosion process and yield only approximate and probable outcome; (2) are not practical for the prediction of soil loss on an event basis; (3) estimate soil erosion on a single slope, instead of within catchments; (4) do not represent the process of sedimentation; (5) are restricted to the sheet and/ or rill erosion; and (6) soil losses and gains over neighbouring areas are not considered (Igwe et al., 2017). In empirical models mostly fieldbased data is utilized and as explained by Parveen and Kumar (2012), USLE (Universal soil loss equation), RUSLE (Revised universal soil loss equation) and MUSLE (Modified universal soil loss equation) are some prominent examples for empirical soil erosion models. Physicallybased models are responsible for modeling the sediment exports and sediment retention in the specific study area and it has the capability to recognize the temporal and spatial variabilities of sediment export and retention processes (Chandramohan et al., 2015). Physically-based models provide an understanding of fundamental sediment producing processes and have the capability to access the spatial and temporal variations of sediment entrainment, transport, and deposition processes (Chandramohan et al., 2015). They described processes involved with the help of mathematical equations dealing with the laws of conservation of energy and mass 
(Morgan, 2005). WEPP (Water erosion prediction project) is one of the most prominent example for physically-based models. In conceptual models, the soil erosion process is conceptualized using soil erosion parameter inputs viz. rainfall-runoff erosivity, soil erodibility, and sediment retention is considered as model output (Chandramohan et al., 2015). AGNPS (Agricultural non-point source pollution) is an important example of a conceptual soil erosion model that was developed to assess potential soil erosion in agricultural watersheds (Lee and Lee, 2006; Jaramillo, 2007). Furthermore, as explained by Anejionu et al. (2013), other numerous erosion models viz. CORINE (Coordination of information on the environment), KINEROS (Kinematic runoff and erosion model), EPM (Erosion potential model), PESERA (Pan-European soil erosion risk assessment), and SLEMSA (Soil Loss Estimation model of Southern Africa), have been developed under different methodologies (Smith, 1999). Moreover, as explained by Jaramillo, (2007) and Merritt et al. (2003), ANSWERS (Areal nonpoint source watershed environment response simulation), CREAMS (Chemicals runoff and erosion from agricultural management systems), and MMF (Morgan, Morgan and Finney model) are the other widely applied soil erosion models in the world.

\section{Application of USLE, RUSLE and InVEST-SR/ SDR Model in Sri Lanka}

USLE, RUSLE, and RUSLE based InVESTSR/SDR model are the most prominent soil erosion models that have been applied in Sri Lanka. Table 01 shows the details viz. scale of application, study area, and objectives of each study. According to the Sri Lankan context, $\sim 50 \%$ of the studies have used RUSLE for the soil erosion modeling while $\sim 29 \%$ and $\sim 21 \%$ of the studies have used USLE and InVEST-SR/ SDR models respectively. Furthermore, $\sim 65 \%$ of the studies have been carried out in catchment or sub-catchment scale whereas $\sim 35 \%$ of studies have been applied in Divisional Secretariat Division, Provincial, and entire country scale. Moreover, as shown in Table 01, the prime aim of each study is to predict soil erosion hazards of the area of interest while each study consists of secondary objectives.

Table 01: Soil erosion modelling studies applied in Sri Lanka with their model type, scale, geographical location and objectives.

\begin{tabular}{|c|c|c|c|c|c|}
\hline $\mathrm{S} / \mathrm{N}$ & Authors & $\begin{array}{l}\text { Model } \\
\text { Applied }\end{array}$ & Scale & Location & Objectives \\
\hline 01 & $\begin{array}{l}\text { (Wijesekara and } \\
\text { Samarakoon, } \\
\text { 2001) }\end{array}$ & USLE & Catchment & $\begin{array}{l}\text { A catchment of } \\
\text { Kegalle District }\end{array}$ & $\begin{array}{c}\text { To extract soil erosion parameters and } \\
\text { to model soil erosion using GIS in a } \\
\text { grid environment }\end{array}$ \\
\hline 02 & $\begin{array}{c}\text { (Senanayake et } \\
\text { al., 2013) }\end{array}$ & USLE & Province & Uva Province & $\begin{array}{l}\text { To prepare soil erosion hazard map for } \\
\text { Uva province } \\
\text { To prepare regional crop suitability } \\
\text { map for Uva province }\end{array}$ \\
\hline 03 & $\begin{array}{l}\text { (Jayarathne et } \\
\text { al., 2010) }\end{array}$ & USLE & $\begin{array}{l}\text { Divisional } \\
\text { Secretariat }\end{array}$ & $\begin{array}{l}\text { Kandeketiya } \\
\text { Divisional } \\
\text { Secretariat }\end{array}$ & $\begin{array}{l}\text { To develop a model for predicting land } \\
\text { degradation using USLE together with } \\
\text { some socio-economic factors }\end{array}$ \\
\hline 04 & $\begin{array}{c}\text { (Senanayake } e t \\
\text { al., 2020) }\end{array}$ & RUSLE & Province & $\begin{array}{c}\text { Sabaragamuwa } \\
\text { Province }\end{array}$ & $\begin{array}{c}\text { To identify the vulnerable landscape } \\
\text { areas using landslide frequency ratio } \\
\text { and land-use change associated soil } \\
\text { erosion hazard }\end{array}$ \\
\hline 05 & $\begin{array}{c}\text { (Dissanayake et } \\
\text { al., 2019) }\end{array}$ & RUSLE & Catchment & $\begin{array}{l}\text { Kotmale } \\
\text { Catchment }\end{array}$ & $\begin{array}{l}\text { To assess the annual soil loss in } \\
\text { Kotmale catchment } \\
\text { To identify conservation priority areas } \\
\text { by using hot and cold spot analysis }\end{array}$ \\
\hline
\end{tabular}


06

07

08

(Lekamge et al., 2018)

09

(Fayas et al., 2019)

(Thuraisingham

10

Weerasinghe, 2009)

11

(Piyathilake et al., 2020)

Kadupitiya,
2018)

13

(Dias et al.,
2019)

14
RUSLE Catchment

InVEST-

\section{SR/SDR}

with

RUSLE

InVEST-

\section{SR/SDR}

with

RUSLE

InVEST-

SR/SDR

with

RUSLE

InVEST-

SR/SDR

with

RUSLE
Province

Country

Subcatchment

Subcatchment
Kalu Ganga

River Basin

Kirindi Oya

River Basin

Kalu Oya and Mudun Ela in Gampaha District

\section{Kelani River}

Basin

Bibili Oya River

Basin

Uva Province

Sri Lanka

Uma Oya Subcatchment

Uma Oya Subcatchment
To estimate the mean annual soil loss in Kalu Ganga river basin

To prepare soil erosion hazard map to prioritize soil conservation areain Kirindi Oya river basin

To assess the vulnerability to soil erosion in Kalu Oya and Mudun Ela.

To assess the annual soil loss in Kelani river basin

To identify soil conservation prioritized areas in Kelani river basin

To calculate average annual sediment yield using sediment delivery ratio and average annual soil loss

To prepare soil erosion hazard map for Bibili Oya river basin

To model predictive assessment of soil erosion related hazards at the Uva province in Sri Lanka

To construct the map of soil erosion hazard zones of Sri Lanka

To assess average annual soil erosion rate in Uma Oya sub-catchment

To assess sediment retention in Uma oya sub-catchment
Derivation of Rainfall Runoff Erosivity Factor (R)

$\mathrm{R}$ factor (MJ $\mathrm{mm}(\mathrm{ha} \mathrm{hr})^{-1}$ ) directly quantifies the impact of rainfall intensity and the mean annual rainfall on soil erosion and it reflects the capability of rainfall to force the soil erosion process with the time (Renard et al., 1997). R factor is the most important parameter in erosion estimation as suggested by several researchers and its correlation with soil loss is high in many regions in the world (Breiby, 2006; Anejionu et al., 2013; Balasubramani et al., 2015; Devatha et al., 2015). In order to calculate $\mathrm{R}$ factor, different methods and equations have been used worldwide concerning the suitability of the methodologies to the area of interest (Igwe et al., 2017) and as explained in Table 02, three types of equations have been used in Sri Lanka to calculate $\mathrm{R}$ factor. In soil erosion modeling studies of Sri Lanka, $76 \%$ of cases, $\mathrm{R}$ factor values have been calculated using the mean annual rainfall values with the correlation developed for Sri Lanka by Wickramasinghe and Premalal (1988) whereas $\sim 15 \%$ and $\sim 8 \%$ of the studies in Sri Lanka have used Roose equation (Roose, 1996) and K.E. > 25 Index method respectively. The soil erosion modeling study that has been conducted in the Uva province, Sri Lanka by Senanayake et al. (2013) is the only study that has used K.E. > 25 Index method to determine $\mathrm{R}$ factor, and this method was presented by Wischmeier and Smith, 
(1965). According to Wischmeier and Smith (1965), the best soil erosion estimation can be achieved by using K.E. $>25$ method. The theory behind this method is when all other parameters are constant, the $\mathrm{R}$ factor is directly proportional to the product of the kinetic energy of the rainfall $(\mathrm{E})$ and its maximum 30-minute rainfall intensity (I) which is obtained by converting the rainfall data $(\mathrm{mm})$ into $\mathrm{mm} /$ hour. This product value is denoted as the $\mathrm{IE}_{30}$ index and this index is continuously utilized to compute monthly and annual rainfall erosivity values. K.E. $>25$ method is more advantageous than the other two methods, since it derives considering many records less than $25 \mathrm{~mm} /$ hour, and uses a lesser amount of rainfall data (Hudson, 1971). But, the major limitation of the $\mathrm{EI}_{30}$ index method is that it has been introduced under USA conditions and is not found appropriate for the Asian regions to estimate the $\mathrm{R}$ factor (Hudson, 1971). The studies carried out by Dias et al. (2019) and Udayakumara and Gunawardena, (2016), have used the Roose equation to calculate the $\mathrm{R}$ factor and the remaining studies used the regression correlation developed for Sri Lanka. These two methods may be suitable for the Sri Lankan conditions since the constants used in these two equations have been developed under tropical, sub-tropical, and Sri Lankan conditions. Furthermore, studies carried out by Jayarathne et al. (2010); Wijesundara et al. (2018), and Panditharathne et al. (2019) show that one mapping tool of $\mathrm{R}$ factor is the Kriging tool in $\operatorname{ArcGIS}^{\mathrm{TM}}$ and QGIS $^{\mathrm{TM}}$ and the other method is Inverse Distance Weighted (IDW) in ArcGIS $^{\mathrm{TM}}$ and QGIS ${ }^{\mathrm{TM}}$ environment. However, with carrying out of cross-validation, it has been revealed that the IDW method has provided the least error for mapping rainfall variability and $\mathrm{R}$ factor over the Kriging method (Panditharathne et al., 2019).

Table 02: Methods used to calculate R factor in GIS and RS based soil erosion modelling studies in Sri Lanka

\begin{tabular}{ccc}
\hline S/N Authors & $\begin{array}{c}\text { Method Used to Calculate } \\
\text { R Factor }\end{array}$ & Equation \\
\hline (Senanayake et al., 2013) & $\begin{array}{c}\text { K.E. > 25 Index method } \\
\text { improved with available } \\
\text { additional data points }\end{array}$ & $\begin{array}{c}\text { Where, KE is rainfall kinetic energy } \\
\text { and } \mathrm{I}_{30} \text { is the maximum rainfall } \\
\text { intensity for a 30-minute period (mm) }\end{array}$ \\
\hline
\end{tabular}

(Piyathilake et al., 2020)

(Senanayake et al., 2020)

(Dissanayake et al., 2019)

(Panditharathne et al., 2019)

(Fayas et al., 2019)

(Wijesundara et al., 2018)

(Jayasekara and Kadupitiya, 2018)

(Jayarathne et al., 2010)

Correlation developed for Sri Lanka using annual rainfall values by Wickramasinghe and Premalal, (1988)
Where, AF is Annual rainfall (mm)

(Thuraisingham and

Weerasinghe, 2009)

(Wijesekara and Samarakoon, 2001)

\begin{tabular}{ccc}
\hline (Dias et al., 2019) & $\begin{array}{c}\text { Calculated using Roose } \\
\text { equation as explained by } \\
\text { (Udayakumara and } \\
\text { Gunawardena, 2016) }\end{array}$ & $\begin{array}{c}\text { Where, a is constant or 0.3 (standard in } \\
\text { tropical mountain areas), } \\
\text { AF is annual rainfall (mm) }\end{array}$ \\
\hline (Lekamge et al., 2018) & Not mentioned & Not mentioned \\
\hline
\end{tabular}




\section{Derivation of Soil Erodibility Factor (K)}

$\mathrm{K}$ factor ( $\mathrm{t}$ ha $\mathrm{hr}(\mathrm{MJ} \text { ha } \mathrm{mm})^{-1}$ ) represents the susceptibility of a given soil type to soil erosion process under the standard unit plot maintained in natural conditions (Sharma, 2010). According to Renard et al. (1991), K factor values vary between 0.05 to 0.45 and it directly depends on the existing soil type in the interested study area. Clay soils have the lowest $\mathrm{K}$ factor values ranges from 0.05 to 0.15 due to having high resistance to soil detachments while soil containing high fractions of sand and silt show relatively high $\mathrm{K}$ factor values that range from 0.25 to 0.45 . In order to measure the erodibility factor, Wischmeier and Smith (1978) proposed a simple procedure measuring five soil properties viz. percentage of organic matter $(\mathrm{OM})$, sand, silt, structure, and permeability. According to scientists, the best method in deriving these soil properties as input to soil erodibility include field-based soil sampling and testing of the area of interest as employed by Yitayew et al. (1999) and then nomography method can be used to derive $\mathrm{K}$ factors for each soil type from soil characteristics found by sampling. However, the shortcoming of this method is its time consumption and laborious nature. But, the general trend in the world for determining $\mathrm{K}$ factor is to use existing data from previous research studies.

As shown in Table 03, approximately $\sim 85 \%$ of the soil erosion modeling studies in Sri Lanka has obtained $\mathrm{K}$ factor values for the area of interest from the available literature of previous studies whereas, only Dissanayake et al. (2019) and Wijesundara et al. (2018) have used nomography to calculate the $\mathrm{K}$ factor values based on properties of soil viz. percentage of organic matter (OM), sand, silt, structure, and permeability. However, using the field-based data and nomography for the derivation of $\mathrm{K}$ values can be more accurate compared to the $\mathrm{K}$ values obtained from previously published literature since $\mathrm{K}$ values can vary according to the climate conditions and the data from previous experiments show that $\mathrm{K}$ is not constant and its variations with seasons (Renard et al., 1991). Nevertheless, since Sri Lanka is a tropical country that does not experience seasonal changes, $\mathrm{K}$ values mostly remain constant for each soil type inside the country. Thus, $\mathrm{K}$ values of above $\sim 85 \%$ of studies are more accurate while $\mathrm{K}$ values of Dissanayake et al. (2019) and Wijesundara et al. (2018) are the most accurate according to the explanation by Renard et al. (1991).

Table 03: $\quad$ Methods used to calculate $K$ factor in GIS and RS based soil erosion modelling studies in Sri Lanka

\begin{tabular}{|c|c|c|c|}
\hline $\mathrm{S} / \mathrm{N}$ & Authors & Method Used to Derive K Factor & References \\
\hline 01 & $\begin{array}{l}\text { (Wijesekara and } \\
\text { Samarakoon, 2001) }\end{array}$ & $\begin{array}{c}\text { From available literature of } \\
\text { previous studies }\end{array}$ & (Joshua, 1977) \\
\hline 02 & $\begin{array}{l}\text { (Senanayake et al., } \\
\text { 2013) }\end{array}$ & $\begin{array}{c}\text { From available literature of } \\
\text { previous studies }\end{array}$ & $\begin{array}{c}\text { (Bandara and Somasiri, 1991) } \\
\text { (Zijister, 1989) }\end{array}$ \\
\hline 03 & (Jayarathne et al., 2010) & $\begin{array}{c}\text { From available literature of } \\
\text { previous studies }\end{array}$ & (Wijesekera and Samarakoon, 2001) \\
\hline 04 & $\begin{array}{l}\text { (Senanayake et al., } \\
\text { 2020) }\end{array}$ & $\begin{array}{c}\text { From available literature of } \\
\text { previous studies }\end{array}$ & $\begin{array}{c}\text { (Fayas et al., 2019) } \\
\text { (Senanayake et al., 2013) } \\
\text { (Wijesekara and Samarakoon, 2001) }\end{array}$ \\
\hline 05 & $\begin{array}{l}\text { (Dissanayake et al., } \\
\text { 2019) }\end{array}$ & $\begin{array}{c}\text { Nomography is used to compute } \\
\text { the values of K based } \\
\text { on soil properties }\end{array}$ & $\begin{array}{l}\text { (Wischmeier and Smith, 1978) } \\
\text { (Ganasri and Ramesh, 2016) } \\
\text { (Mapa et al., 2010) }\end{array}$ \\
\hline 06 & $\begin{array}{l}\text { (Panditharathne et al., } \\
\text { 2019) }\end{array}$ & $\begin{array}{c}\text { From available literature of } \\
\text { previous studies }\end{array}$ & $\begin{array}{l}\text { (Jayarathne et al., 2010) } \\
\text { (Wijesundara et al., 2018) } \\
\quad \text { (Fayas et al., 2019) }\end{array}$ \\
\hline
\end{tabular}




\begin{tabular}{|c|c|c|c|}
\hline $\mathrm{S} / \mathrm{N}$ & Authors & Method Used to Derive K Factor & References \\
\hline 07 & $\begin{array}{l}\text { (Wijesundara et al., } \\
\text { 2018) }\end{array}$ & $\begin{array}{c}\text { From available literature and } \\
\text { Nomography is used to compute } \\
\text { the values of } \mathrm{K} \text { based on soil } \\
\text { properties }\end{array}$ & $\begin{array}{c}\text { (Joshua, 1977) } \\
\text { (Wijesekara and Samarakoon, 2002) } \\
\text { (Mapa et al., 2010) }\end{array}$ \\
\hline 08 & (Lekamge et al., 2018) & $\begin{array}{c}\text { From available literature of } \\
\text { previous studies }\end{array}$ & Not mentioned \\
\hline 09 & (Fayas et al., 2019) & $\begin{array}{c}\text { From available literature of } \\
\text { previous studies }\end{array}$ & $\begin{array}{c}\quad \text { (Joshua, 1977) } \\
\text { (Wijesekera and Samarakoon, 2001) }\end{array}$ \\
\hline 10 & $\begin{array}{l}\text { (Thuraisingham and } \\
\text { Weerasinghe, 2009) }\end{array}$ & $\begin{array}{c}\text { From available literature of } \\
\text { previous studies }\end{array}$ & (Joshua, 1977) \\
\hline 11 & (Piyathilake et al., 2020) & $\begin{array}{c}\text { From available literature of } \\
\text { previous studies }\end{array}$ & $\begin{array}{c}\text { (Fayas et al., 2019) } \\
\text { (Hasselo and Sikurajapathy, 1985) } \\
\text { (Jayarathne } \text { et al., 2010) } \\
\text { (Joshua, 1977) } \\
\text { (Mapa et al., 2010) } \\
\text { (Wijesekara and Samarakoon, 2002) } \\
\text { (Wijesundara et al., 2018) } \\
\text { (Zijister, 1989) }\end{array}$ \\
\hline 12 & $\begin{array}{c}\text { (Jayasekara and } \\
\text { Kadupitiya, 2018) }\end{array}$ & $\begin{array}{c}\text { From available literature of } \\
\text { previous studies }\end{array}$ & (Joshua, 1977) \\
\hline 13 & (Dias et al., 2019) & $\begin{array}{c}\text { From available literature of } \\
\text { previous studies }\end{array}$ & (Weerasinghe et al., 2016) \\
\hline 14 & $\begin{array}{l}\text { (Udayakumara and } \\
\text { Gunawardena, 2016) }\end{array}$ & $\begin{array}{c}\text { From available literature of } \\
\text { previous studies }\end{array}$ & (Hasselo and Sikurajapathy, 1985) \\
\hline
\end{tabular}

\section{Derivation of Slope Gradient Factor (LS)}

The slope gradient factor (LS) represents the collective effect of the slope length (L) and slope steepness (S) on the soil erosion process (Wischmeier and Smith, 1978). Generally, the $\mathrm{L}$ and $\mathrm{S}$ factor considered together as the slope gradient factor, and both $\mathrm{L}$ and $\mathrm{S}$ factor values are equal to 1 for the standard unit plot conditions of 9\% steepness and $72.6 \mathrm{ft}$. length (Renard et al., 1997). Haan et al. (1994), revealed that when the LS factor is increased, a corresponding increase in erosion owing to increased velocity of the water flow can be seen. Thus soil loss increase proportionately with the increase in length and incline of slope and the combined effects of slope length and slope incline gives a good estimate of soil erosion rate (McCool et al., 1987).

According to the previous studies of soil erosion modeling in Sri Lanka, in order to calculate the LS factor, manual methods that have been originally proposed by Wischmeier and Smith (1978) and GIS/RS-based calculation methods have been used. According to Table 04, different equations and methodologies have been used to calculate LS factors and in $\sim 85 \%$ of the studies, LS factor has been calculated using GIS-based methods while only Jayarathne et al. (2010) and Wijesekara and Samarakoon, (2001) have calculated LS factors using manual methods. At the catchment or small scale, this manual derivation methods of LS factors are accurate and manageable whereas it is hardly possible at whole country or large scales in terms of its practicability. Also, another criticism of the manual methods of calculating LS factors is its narrow applicability to complex variable topography (Desmet and Govers, 1996). But, with the improvements in GIS/RS technology, the derivation methods of LS factor have become more significant and this method explicitly accounts for modeling soil erosion over a for more topographically complex landscapes over 
a large extent (Wilson and Gallant, 2000). Thus, $\sim 85 \%$ of the cases in Sri Lankan studies have used GIS/RS based derivation methods of LS factor with the disadvantages viz. requirement of high-resolution DEMs for an accurate representation of the topography, cannot capture the convergence and divergence of flow network of a catchment that ultimately drives to accuracy issues as explained by Benavidez et al. (2018).

Table 04: Methods used to calculate LS factor in GIS and RS based soil erosion modelling studies in Sri Lanka

\begin{tabular}{lc}
\hline $\mathrm{S} / \mathrm{N}$ & Authors \\
\hline 01 & (Senanayake et al., 2013) \\
\hline
\end{tabular}

Method Used to Derive LS Factor

02 (Senanayake et al., 2020)

The LS layer has derived directly from slope and flow accumulation layers, both of which can be computed using the digital elevation model (DEM).

$L S=\left(\frac{\text { Flow accumulation } \times \text { Cell size }}{22.13}\right)^{0.4} \times \operatorname{Sin}\left(\frac{\text { Slope angle in degrees }}{0.0896}\right)^{1.3}$

$$
L=(\mu / 72.6) m
$$

03 (Jayarathne et al., 2010)

Where, $\mu$ is slope length and $\mathrm{m}$ is a slope dependent parameter.

Value for $\mathrm{m}$ was taken as 0.3 for slopes less than $5 \%, 0.6$ for slopes greater than $10 \%$ and 0.5 for slopes in between

$$
S=\left(0.43+0.3 s+0.043 s^{2}\right) / 6.613
$$

Where, $\mathrm{S}$ is the slope gradient in percentage

(Wijesekera and Samarakoon, 2001)

$05 \quad$ (Panditharathne et al., 2019)

$06 \quad$ (Fayas et al., 2019)

07 (Wijesundara et al., 2018) Weerasinghe, 2009)
$08 \quad$ (Thuraisingham and

$$
L=(\lambda / 22.1) \mathrm{m}
$$

Where, $\lambda$ is horizontal projected slope length $(\mathrm{m})(\lambda=$ flow accumulation *cell size), and $\mathrm{m}$ is slope length exponent.

(Renard et al., 1997)

$$
\begin{gathered}
S=10.8 \sin \theta+0.03 \text { for slope percent }<9 \% \\
S=10.8 \sin \theta-0.50 \text { for slope percent } \geq 9 \% \\
\theta \text { is slope angle in degrees } \\
\text { (Wischmeier and Smith, 1978) }
\end{gathered}
$$

LS factor has been calculated using flow accumulation and slope gradient. Ultimately, LS map has been prepared by the multiplication of both $\mathrm{L}$ and $\mathrm{S}$ factors in raster calculator in ArcGIS.

$$
L S=\left(\frac{Q a M^{y}}{22.13}\right) \times\left(0.65+0.045 \times S_{g}+0.65 \times S_{g}^{2}\right)
$$

Where, $\mathrm{Q}$ is the flow accumulation grid, $\mathrm{M}$ is the grid size, $\mathrm{y}$ is the dimensional exponent and $\mathrm{S}_{\mathrm{g}}$ is the angle of the slope.

09 (Dissanayake et al., 2019)

(Balasubramani et al., 2015; Ganasri and Ramesh, 2016; Lu et al., 2004)

LS factor has been calculated using flow accumulation and slope gradient. Ultimately, LS map has been prepared by the multiplication of both $\mathrm{L}$ and $\mathrm{S}$ factors in raster calculator in ArcGIS. 


\begin{tabular}{cc}
\hline $\mathrm{S} / \mathrm{N}$ & Authors \\
\hline 10 & (Piyathilake et al., 2020) \\
\hline 11 & (Jayasekara and Kadupitiya, \\
\hline
\end{tabular}

12 (Dias et al., 2019)

13 (Udayakumara and Gunawardena, 2016)
Method Used to Derive LS Factor

$$
L=(\lambda / 22.1) \mathrm{m}
$$

Where, $\lambda$ is horizontal projected slope length $(\mathrm{m})(\lambda=$ flow accumulation *cell size), and $\mathrm{m}$ is slope length exponent.

(Renard et al., 1997)

$$
\begin{gathered}
S=10.8 \sin \theta+0.03 \text { for slope percent }<9 \% \\
S=10.8 \sin \theta-0.50 \text { for slope percent } \geq 9 \% \\
\theta \text { is slope angle in degrees } \\
\text { (Wischmeier and Smith, 1978) }
\end{gathered}
$$

$$
\begin{aligned}
& \text { The LS factor is derived from the InVEST-SR/SDR model, both of } \\
& \text { which can be computed using the digital elevation model (DEM) }
\end{aligned}
$$

(Sharp et al., 2018)

Not mentioned

\section{Derivation of Cover Management Factor (C)}

The $\mathrm{C}$ factor characterizes the effects of land use on soil erosion rates in a standard unit plot at a given time (Jayasekara and Kadupitiya, 2018). C factor values are possibly one of the most important factors since it indicates how soil conservation practices affect the mean annual soil loss rates and how soil erosion potential is distributed over the study area. C factor values generally vary from 0 to 1.5 whereas, 0 or nearly 0 values assigned for the finely protected lands with proper crop management systems and $0<$ values assigned for considerably tilled lands that are highly vulnerable to soil erosion (Renard et al., 1997). According to the previous studies, two derivation methods of $\mathrm{C}$ factor have been presented as (1) Referencing from previously conducted studies for similar land use classes in similar countries or regions. (2) Novel derivation method of $\mathrm{C}$ factor using NDVI (Normalized difference vegetation index) with $\mathrm{RS}$ and satellite imagery techniques (Benavidez et al., 2018).

As shown in Table 05, out of the above mentioned two methodologies, $\sim 93 \%$ of the Sri Lankan studies (Piyathilake et al., 2020; Senanayake et al., 2020; Dias et al., 2019; Fayas et al., 2019; Panditharathne et al., 2019; Jayasekara and Kadupitiya, 2018; Lekamge et al., 2018; Jayarathne et al., 2010; Thuraisingham and Weerasinghe, 2009; Udayakumara and
Gunawardena, 2016; Wijesundara et al., 2018; Wijesekara and Samarakoon, 2001) have used previous literature to determine $\mathrm{C}$ factor which is the simplest and time-saving method since the NDVI method requires advance RS applications viz. satellite imagery, aerial photography, and image processing. According to the Sri Lankan studies, Dissanayake et al. (2019) has found to be the only study that has used the NDVI method to determine the $\mathrm{C}$ factor by computing the vegetation cover in the area of interest. NDVI is an effective method of investigating surface land use practices and vegetation cover (Ranagalage et al., 2018). In Sri Lanka studies, Dissanayake et al. (2019) has used the following equation to derive the $\mathrm{C}$ factor where, $\alpha$ is equal to $1, \beta$ is equal to 2 (Alexakis et al., 2013).

$$
C=\exp \left[-\alpha \frac{N D V I}{(\beta-N D V I)}\right]
$$

Many scientists also have used the NDVI method for the derivation of $\mathrm{C}$ factor in the world viz. (Prasannakumar et al., 2012; Alexakis et al., 2013; Adarsh et al., 2016 and Dutta, 2016) and found that this approach is effective and gives accurate $\mathrm{C}$ factor values in different scenarios. Although $\sim 93 \%$ of studies have incorporate $C$ factor values to model soil erosion using GIS/ RS technologies, Senanayake et al. (2013) explains that, since the $\mathrm{C}$ factors are highly localized and vary at individual farm level, its effects are 
scattered and it will not vital to apply $\mathrm{C}$ factor for regional-scale studies. Thus, the only land cover factor has been taken into consideration.

\section{Derivation of Support Practice Factor (P)}

The P factor reflects the support practices and soil conservation practices viz. terracing and contouring that affect the rate of soil erosion through conserving and transforming the flow patterns (Renard et al., 1997). According to Bagherzadeh (2014), the $\mathrm{P}$ factor ranges from 0 to 1 whereas 0 denotes well-conserved soil with good land management practices that mitigate soil erosion and 1 denotes poor soil conservation practices that allow the soil to lose and export easily. For instance, the $\mathrm{P}$ factor of 1 reflects conventional tillage practices in highlands which allow the soil to erode without obstructions while the $\mathrm{P}$ factor of 0.25 reflects the soil conservation practice which is capable of reducing the soil loss by $75 \%$. Furthermore, $\mathrm{P}$ factors can also be utilized as a direct recognition of how soil conservation practices are effective in land management practices (Benavidez et al., 2018).

Table 05: References used for the determination of $\mathrm{C}$ factor in GIS and RS based soil erosion modelling studies in Sri Lanka

\begin{tabular}{|c|c|c|}
\hline $\mathrm{S} / \mathrm{N}$ & Authors & References Used to Determine C Factor \\
\hline 01 & (Panditharathne et al., 2019) & $\begin{array}{l}\text { (Wijesundara et al., 2018) } \\
\text { (Fayas et al., 2019) } \\
\text { (Munasinghe } \text { et al., 2001) } \\
\text { (Biswas and Pani, 2015) }\end{array}$ \\
\hline 02 & (Jayarathne et al., 2010) & Not mentioned \\
\hline 03 & (Wijesundara et al., 2018) & $\begin{array}{l}\text { (Munasinghe } \text { et al., 2001) } \\
\text { (Senanayake } \text { et al., 2013) }\end{array}$ \\
\hline 04 & (Fayas et al., 2019) & $\begin{array}{l}\text { (Munasinghe et al., 2001) } \\
\text { (Senanayake } \text { et al., 2013) } \\
\text { (Wijesundara } \text { et al., 2018) }\end{array}$ \\
\hline 05 & (Thuraisingham and Weerasinghe, 2009) & (Wijesekera and Samarakoon, 2001) \\
\hline 06 & (Jayasekara and Kadupitiya, 2018) & (Kuok et al., 2013) \\
\hline 07 & (Dias et al., 2019) & $\begin{array}{c}\text { (Udayakumara and Gunawardena, 2016) } \\
\text { (Weerasinghe } \text { et al., 2016) }\end{array}$ \\
\hline 08 & (Udayakumara and Gunawardena, 2016) & (Kuok et al., 2013) \\
\hline 09 & (Lekamge et al., 2018) & Not mentioned \\
\hline 10 & (Piyathilake et al., 2020) & $\begin{array}{c}\text { (Biswas and Pani, 2015) } \\
\text { (Kuok et al., 2013) } \\
\text { (Munasinghe et al., 2001) } \\
\text { (Senanayake et al., 2013) } \\
\text { (Udayakumara and Gunawardena, 2016) } \\
\text { (Weerasinghe } \text { et al., 2016) } \\
\text { (Wijesekera and Samarakoon, 2001) } \\
\text { (Wijesundara } \text { et al., 2018) }\end{array}$ \\
\hline 11 & (Wijesekara and Samarakoon, 2001) & Not mentioned \\
\hline 12 & (Senanayake et al., 2020) & $\begin{array}{l}\text { (Senanayake } \text { et al., 2013) } \\
\text { (Munasinghe et al., 2001) }\end{array}$ \\
\hline
\end{tabular}


Similar to the $\mathrm{C}$ factor, $\mathrm{P}$ factors can also be obtained referring to previously published literature related to the interested area or region that the study about to be conducted. As explained by Adornado and Yoshida, (2010), some of the soil erosion modeling studies that have been carried out on a large scale omitted including the $\mathrm{P}$ factor for the model due to the complexity and diverse nature of soil conservation methods that scattered throughout the large study area. In such cases, scientists have replaced the $\mathrm{P}$ factor by the value of 1 . This method has been used in the Sri Lankan context by Jayarathne et al. (2010) to determine $\mathrm{P}$ factors for the area of Kandeketiya Divisional Secretariat. Furthermore, one of the most possible reasons for omitting the $\mathrm{P}$ factor in some studies is due to some $\mathrm{C}$ factor values already describe support practices with their $\mathrm{C}$ factor values. For instance, Senanayake et al. (2013) has given C factor values concerning land management practices as well and in this case, the $\mathrm{P}$ factor is omitted. Moreover, $\sim 86 \%$ of Sri Lanka soil erosion modeling studies have used previously published data for obtaining $\mathrm{P}$ factor values for each land use and land cover classes (Wijesekara and Samarakoon, 2001; Thuraisingham and Weerasinghe, 2009; Udayakumara and Gunawardena, 2016; Lekamge et al., 2018; Jayasekara and Kadupitiya, 2018; Wijesundara et al., 2018; Dias et al., 2019; Fayas et al., 2019; Panditharathne et al., 2019; Piyathilake et al., 2020; Senanayake et al., 2020).

\section{CONCLUSIONS AND RECOMMENDATIONS}

USLE, along with its family of soil erosion models viz. RUSLE and RUSLE based InVESTSR/SDR models are the most extensively applied models in Sri Lanka. Although these models are recommended for small scale spatially distributed catchments, it has been established that these models estimate soil losses and sediment delivery ratios accurately in different geographical scales such as large catchment, divisional secretariat, province, and whole country scales. Previous literature on soil erosion models in Sri Lanka has shown that the different erosion modeling components ( $\mathrm{R}$ factor, $\mathrm{K}$ factor, LS factor, $\mathrm{C}$ factor, and $\mathrm{P}$ factor) can be derived using many data sources and materials viz. DEM data, rainfall data, the spatial distribution of soil types data, and delineated river basin maps and some advance equations in soil erosion studies.

However, this review explains the methodologies that have been used for the derivation of soil erosion model parameters in Sri Lankan studies and it clearly shows the most appropriate derivation methods and equations of five soil erosion model parameters depending on the geographical scale of the study and availability of data adapting to the unique conditions of the study area. Furthermore, this review clarifies how future researchers will be able to select the best method of deriving R, K, LS, C, and $\mathrm{P}$ factor overcoming the challenges viz. limited data availability and complexity of applying soil erosion models that are associated with running soil erosion models.

The following recommendations are worth mentioning for future soil erosion studies with USLE, RUSLE, and RUSLE based InVEST-SR/ SDR models in a GIS/ RS environment:

- Although K.E. $>25$ method is a comparatively more advantageous method of deriving $\mathrm{K}$ factor compared with other methods, it has been introduced under USA conditions and is not found appropriate for the Asian regions to estimate the $\mathrm{R}$ factor. Thus, using the Roose equation and the regression correlation developed for Sri Lanka to calculate the R factor may be the most suitable methods for the Sri Lankan conditions since the constants used in these two equations have been developed under tropical, sub-tropical, and Sri Lankan conditions.

- The method of using Soil Erodibility Nomography based on soil properties (percentage of organic matter $(\mathrm{OM})$, sand, silt, structure, and permeability) is the comparatively more accurate method of deriving $\mathrm{K}$ factor in soil erosion modeling.

- At the catchment or small scale, manual derivation methods of LS factors are more accurate and manageable whereas it is hardly possible at large scales or at complex 
topographies where GIS-based methods can be recommended.

- Although many studies have used previously published literature to derive $\mathrm{C}$ factor, the comparatively more accurate method is to use the NDVI method, since it uses satellite imagery, aerial photography of the exact study area to derive $\mathrm{C}$ factor for each land use type.

- Further development of a method to effectively derive $\mathrm{P}$ factor is highly required since all the previous soil erosion studies have obtained $\mathrm{P}$ factor referring to the previously published literature.
- When we consider soil erosion assessments, $\mathrm{R}, \mathrm{C}$, and $\mathrm{P}$ factors are more decisive factors of soil erosion in any region as they change during a very short period. Even though, the $\mathrm{C}$ and $\mathrm{P}$ factors are considered decisive factors of soil loss, while applying proper soil and water conservation measures their impact can be minimized. However, the K and LS factors are not changed during a very short period and they can be considered as less important factors for short term soil erosion predictions.

\section{REFERENCES}

Adarsh, S., VishnuPriya, M.S., Narayanan, S., Smruthi, M.S., George, P. and Benjie, N.M. (2016). Trend analysis of sediment flux time series from tropical river basins in India using nonparametric tests and multiscale decomposition. Modeling Earth Systems and Environment, 2(4), pp.1-16. DOI: https://doi.org/10.1007/s40808-016-0245-0

Adornado, H.A. and Yoshida, M. (2010). Assessing the Adverse Impacts of Climate Change: A Case Study in the Philippines. Journal of Developments in Sustainable Agriculture, 5(1), pp.141146. DOI: https://doi.org/10.11178/jdsa.5.141

Alewell, C., Borrelli, P., Meusburger, K. and Panagos, P., 2019. Using the USLE: Chances, challenges and limitations of soil erosion modelling. International soil and water conservation research, 7(3), pp.203-225. DOI: https://doi.org/10.1016/j.iswcr.2019.05.004

Alexakis, D.D., Hadjimitsis, D.G. and Agapiou, A. (2013). Integrated use of remote sensing, GIS and precipitation data for the assessment of soil erosion rate in the catchment area of "Yialias" in Cyprus. Atmospheric Research, 131, pp.108-124. DOI: https://doi.org/10.1016/j. atmosres.2013.02.013

Anejionu, O.C., Nwilo, P.C. and Elijah, S.E., 2013. Long Term Assessment and Mapping of Erosion Hotspots in South East Nigeria. Remote Sensing for Landuse and Planning-6448Abuja, Nigeria, pp.1-19. Retrived from https://www.fig.net/resources/proceedings/fig_proceedings/fig2013/ papers/TS03B/TS03B_anejionu_nwilo_et_al_6448.pdf

Bagherzadeh, A., 2014. Estimation of soil losses by USLE model using GIS at Mashhad plain, Northeast of Iran. Arabian Journal of Geosciences, 7(1), pp.211-220. DOI: https://doi. org/10.1007/s12517-012-0730-3

Balasubramani, K., Veena, M., Kumaraswamy, K. and Saravanabavan, V., 2015. Estimation of soil erosion in a semi-arid watershed of Tamil Nadu (India) using revised universal soil loss equation (rusle) model through GIS. Modeling Earth Systems and Environment, 1(3), p.10. DOI: https:// doi.org/10.1007/s40808-015-0015-4

Bandara, T., Somasiri, (1991). Integration of resource data for soil erosion hazard assessment and mapping in Nuwaraeliya and Kandy districts. Tropical Agriculturist 147, pp.59-73. 
Benavidez, R., Jackson, B., Maxwell, D. and Norton, K. (2018). A review of the (Revised) Universal Soil Loss Equation ((R) USLE): with a view to increasing its global applicability and improving soil loss estimates. Hydrology and Earth System Sciences, 22(11), pp.6059-6086. DOI: https:// doi.org/10.5194/hess-22-6059-2018

Bhattarai, R. and Dutta, D. (2007). Estimation of soil erosion and sediment yield using GIS at catchment scale. Water Resources Management, 21(10), pp.1635-1647. DOI: https://doi. org/10.1007/s11269-006-9118-z

Biswas, S.S. and Pani, P. (2015). Estimation of soil erosion using RUSLE and GIS techniques: a case study of Barakar River basin, Jharkhand, India. Modeling Earth Systems and Environment, 1(4), p.42. DOI: https://doi.org/10.1007/s11269-006-9118-z

Breiby, T. (2006). Assessment of soil erosion risk within a subwatershed using GIS and RUSLE with a comparative analysis of the use of STATSGO and SSURGO soil databases. Papers in Resource Analysis, 8, pp.1-22. Retrived from: http://www.gis.smumn.edu/gradprojects/breibyt.pdf

Castro Filho, C., Cochrane, T.A., Norton, L.D., Caviglione, J.H. and Johansson, L.P. (2001). Land degradation assessment: tools and techniques for measuring sediment load. Retrived from: https://ir.canterbury.ac.nz/handle/10092/179

Chandramohan, T., Venkatesh, B. and Balchand, A.N. (2015). Evaluation of three soil erosion models for small watersheds. Aquatic Procedia, 4, pp.1227-1234. DOI: https://doi.org/10.1016/j. aqpro.2015.02.156

Cheng, X., Chen, L., Sun, R. and Kong, P. (2018). Land use changes and socio-economic development strongly deteriorate river ecosystem health in one of the largest basins in China. Science of the Total Environment, 616, pp.376-385. DOI: https://doi.org/10.1016/j.scitotenv.2017.10.316

Desmet, P.J.J. and Govers, G. (1996). A GIS procedure for automatically calculating the USLE LS factor on topographically complex landscape units. Journal of soil and water conservation, 51(5), pp.427-433. Retrived from: https://www.jswconline.org/content/51/5/427

Devatha, C.P., Deshpande, V. and Renukaprasad, M.S. (2015). Estimation of soil loss using USLE model for Kulhan Watershed, Chattisgarh-A case study. Aquatic Procedia, 4, pp.1429-1436. Retrived from: https://cyberleninka.org/article/n/324500.pdf

Dias, B.A.R.H., Udayakumara, E.P.N., Jayawardana, J.M.C.K., Malavipathirana, S. and Dissanayake, D.A.T.W.K. (2019). Assessment of Soil Erosion in Uma Oya Catchment, Sri Lanka. Journal of Environmental Professionals Sri Lanka, 8(1). DOI: http://doi.org/10.4038/jepsl.v8i1.7875

Dissanayake, D.M.S.L.B., Morimoto, T. and Ranagalage, M. (2019). Accessing the soil erosion rate based on RUSLE model for sustainable land use management: A case study of the Kotmale watershed, Sri Lanka. Modeling Earth Systems and Environment, 5(1), pp.291-306. DOI: https://doi.org/10.1007/s40808-018-0534-x

Diyabalanage, S., Samarakoon, K.K., Adikari, S.B. and Hewawasam, T. (2017). Impact of soil and water conservation measures on soil erosion rate and sediment yields in a tropical watershed in the Central Highlands of Sri Lanka. Applied Geography, 79, pp.103-114. DOI: https://doi. org/10.1016/j.apgeog.2016.12.004

Dutta, S. (2016). Soil erosion, sediment yield and sedimentation of reservoir: a review. Modeling Earth Systems and Environment, 2(3), p.123. DOI: https://doi.org/10.1007/s40808-016-0182-y 
FAO (2015). Status of the World's Soil Resources (SWSR)-technical summary Food and Agriculture Organization of the United Nations and Intergovernmental Technical Panel on Soils, Rome, Italy. Retrived from: http://www.fao.org/documents/card/en/c/c6814873-efc3-41db-b7d32081a10ede50/

Fayas, C.M., Abeysingha, N.S., Nirmanee, K.G.S., Samaratunga, D. and Mallawatantri, A. (2019). Soil loss estimation using rusle model to prioritize erosion control in KELANI river basin in Sri Lanka. International Soil and Water Conservation Research, 7(2), pp.130-137. DOI: https:// doi.org/10.1016/j.iswcr.2019.01.003

Ganasri, B.P. and Ramesh, H. (2016). Assessment of soil erosion by RUSLE model using remote sensing and GIS-A case study of Nethravathi Basin. Geoscience Frontiers, 7(6), pp.953-961. DOI: https://doi.org/10.1016/j.gsf.2015.10.007

Gunawan, G., Sutjiningsih, D., Soeryantono, H. and Sulistioweni, S. (2013). Soil erosion estimation based on GIS and remote sensing for supporting integrated water resources conservation management. International Journal of Tecnology, 4(2), pp.157-166. Retrived from: http:// repository.unib.ac.id/id/eprint/7502

Haan, C.T., Barfield, B.J. and Hayes, J.C. (1994). Design hydrology and sedimentology for small catchments. Elsevier. Retrived from: https://scholar.google.com/scholar?hl=en\&as $\mathrm{sdt}=0 \% 2 \mathrm{C} 5 \& \mathrm{q}=$ Haan $+\mathrm{CT} \% 2 \mathrm{C}+$ Barfield $+\mathrm{BJ} \% 2 \mathrm{C}+$ Hayes $+\mathrm{JC}+\% 281994 \% 29+$ Design + hydrology + and + sedimentology + for + small + catchments. + Elsevier $\% 2 C+\& b \operatorname{tnG}=$

Han, F., Ren, L., Zhang, X. and Li, Z. (2016). The WEPP Model application in a small watershed in the Loess Plateau. PloS one, 11(3).DOI: https://doi.org/10.1371/journal.pone.0148445

Hasselo, H.N. and Sikurajapathy, M. (1965). Estimations of the losses and erodibility of tea soils during the replanting period. Journal of National Agricultural Society of Ceylon, 2, pp.13-21.

Hewawasam, T., von Blanckenburg, F., Schaller, M. and Kubik, P., 2003. Increase of human over natural erosion rates in tropical highlands constrained by cosmogenic nuclides. Geology, 31(7), pp.597-600. DOI: https://doi.org/10.1130/0091-7613(2003)031\%3C0597:iohone\%3E2.0.co;2

Hewawasam, T., 2010. Effect of land use in the upper Mahaweli catchment area on erosion, landslides and siltation in hydropower reservoirs of Sri Lanka. Journal of the National Science Foundation of Sri Lanka, 38(1). DOI: https://doi.org/10.4038/jnsfsr.v38i1.1721

Hudson, N.W. (1971). A textbook of Soil Conservation. BT Batsford Limited, 50(52), pp.58-60.

Igwe, P., Onuigbo, A., Chinedu, O., Ezeaku, I., Muoneke, M. (2017). Soil erosion: A review of models and applications, International Journal of Advanced Engineering Research and Science, 4:12. DOI: https://dx.doi.org/10.22161/ijaers.4.12.22

Issaka, S. and Ashraf, M.A. (2017). Impact of soil erosion and degradation on water quality: a review. Geology, Ecology, and Landscapes, 1(1), pp.1-11.DOI: https://doi.org/10.1080/24749 508.2017.1301053

Jahun, B.G., Ibrahim, R., Dlamini, N.S. and Musa, S.M. (2015). Review of soil erosion assessment using RUSLE model and GIS. J Biol Agric Healthc, 5(9).

Jaramillo, F. (2007). Estimating and modeling soil loss and sediment yield in the Maracas-St. Joseph River Catchment with empirical models (RUSLE and MUSLE) and a physically based model (Erosion 3D) (Doctoral dissertation, McGill University). 
Jayarathne, K.D.B.L., Dayawansa, N.D.K. and De Silva, R.P. (2010). GIS based analysis of biophysical and socio-economic factors for land degradation in Kandaketiya DS division, Tropical Agricultural Research Vol. 21(4), pp.361 - 367. Retrived from: http://thesis.pgia.ac.lk/ bitstream/1/2140/2/PGIATAR-21\%284\%29-361.pdf

Jayasekara, M.J.P.T.M., Kadupitiya, H.K. and Vitharana, U.W.A. (2018). Mapping of soil erosion hazard zones of Sri Lanka. Tropical Agricultural Research, 29(2), pp.135-146. Retrived from: https://www.researchgate.net/profile/Thilini_Jayasekara/publication/328412425_Mapping_ of_Soil_Erosion_Hazard_Zones_of_Sri_Lanka/links/5bcbf4f3458515f7d9ce343a/Mappingof-Soil-Erosion-Hazard-Zones-of-Sri-Lanka.pdf

Joshua, W.D. (1977). Soil erosive power of rainfall in the different climatic zones of Sri Lanka. In Erosion and Solid Matter Transport in Inland Waters, Proceedings of Symposium. Publ (No. 122), pp. 51-61. Retrived from: http://hydrologie.org/redbooks/a122/iahs_122_0051.pdf

Kuok, K.K., Mah, D.Y. and Chiu, P.C. (2013). Evaluation of C and P factors in universal soil loss equation on trapping sediment: case study of Santubong River. Journal of Water Resource and Protection, 2013. DOI: http://www.scirp.org/journal/PaperInformation.aspx?PaperID=40547

Laflen, J.M. and Flanagan, D.C. (2013). The development of US soil erosion prediction and modeling. International Soil and Water Conservation Research, 1(2), pp.1-11. DOI: https://doi. org/10.1016/S2095-6339(15)30034-4

Lal, R.A.T.T.A.N., 2001. Soil degradation by erosion. Land degradation \& development, 12(6), pp.519-539. DOI: https://doi.org/10.1002/1dr.472

Lee, G.S. and Lee, K.H. (2006). Scaling effect for estimating soil loss in the RUSLE model using remotely sensed geospatial data in Korea. Hydrology and Earth System Sciences Discussions 3, pp.135-157. DOI: https://doi.org/10.5194/hessd-3-135-2006

Lekamge, M.L.D., Dayananda, M.D.N.R. and Weerasinghe, V.P.A. (2018). Estimation of crop management factor and conservation support practice factor of RUSLE model to assess vulnerability to soil erosion in Kalu Oya and Mudun Ela basins using GIS. In International Research Symposium on Pure and Applied Sciences, (26 October), Faculty of Science, University of Kelaniya, Sri Lanka.

Li, L., Du, S., Wu, L. and Liu, G., 2009. An overview of soil loss tolerance. Catena, 78(2), pp.93-99. DOI: https://doi.org/10.1016/j.catena.2009.03.007

Lu, D., Li, G., Valladares, G.S. and Batistella, M. (2004). Mapping soil erosion risk in Rondonia, Brazilian Amazonia: using RUSLE, remote sensing and GIS. Land degradation \& development, 15(5), pp.499-512. DOI: https://doi.org/10.1002/ldr.634

Mapa, R., Somasiri, S., and Dassanayake, A,. (2010). Soils of the Dry zone of Sri Lanka. In: Morphology, Characterization and Classification Special Publication No7 Soil science society of Sri Lanka.

McCool, D.K., Brown, L.C., Foster, G.R., Mutchler, C.K. and Meyer, L.D. (1987). Revised slope steepness factor for the Universal Soil Loss Equation. Transactions of the ASAE, 30(5), pp.13871396. Retrived from: https://elibrary.asabe.org/abstract.asp?aid=31192

Merritt, W.S., Letcher, R.A. and Jakeman, A.J. (2003). A review of erosion and sediment transport models. Environmental Modelling \& Software, 18(8-9), pp.761-799. DOI: https://doi. org/10.1016/S1364-8152(03)00078-1 
Moehansyah, H., Maheshwari, B.L. and Armstrong, J. (2004). Field evaluation of selected soil erosion models for catchment management in Indonesia. Biosystems Engineering, 88(4), pp.491-506. DOI: https://doi.org/10.1016/j.biosystemseng.2004.04.013

Morgan, R.P.C. (2005). Soil Erosion and Conservation. Third edition. Blackwell Publishing, Malden, U.S.A.

Munasinghe, M.A.K., Pushpakumara, V., Bandara, T.M.J. and Herath, H.M.B. (2001). Use of information systems for soil erosion hazard assessment of the central province of Sri Lanka. Annals of Department of Agriculture, 3, p.148.

Nayakekorala, H.B., 1998. Human induced soil degradation status in Sri Lanka. Journal of Soil Science Society of Sri Lanka, 10, pp.1-35.

Onyando, J.O., Kisoyan, P. and Chemelil, M.C. (2005). Estimation of potential soil erosion for river perkerra catchment in Kenya. Water Resources Management, 19(2), pp.133-143. DOI: https:// doi.org/10.1007/s11269-005-2706-5

Panditharathne, D.L.D., Abeysingha, N.S., Nirmanee, K.G.S. and Mallawatantri, A. (2019). Application of Revised Universal Soil Loss Equation (Rusle) Model to Assess Soil Erosion in "Kalu Ganga" River Basin in Sri Lanka. Applied and Environmental Soil Science, 2019. DOI: https://doi.org/10.1155/2019/4037379

Parveen, R. and Kumar, U. (2012). Integrated approach of universal soil loss equation (USLE) and geographical information system (GIS) for soil loss risk assessment in Upper South Koel Basin, Jharkhand. Retrived from: http://www.scirp.org/journal/PaperInformation. aspx?PaperID=26324

Phai, D.D., Orange, D., Migraine, J.B., Toan, T.D. and Vinh, N.C. (2007). Applying GIS-assisted modelling to predict soil erosion for a small agricultural watershed within sloping lands in Northern Vietnam. Retrived from: https://hdl.handle.net/10568/38619

Pimentel, D.,Allen, J., Beers,A., Guinand, L., Linder, R., McLaughlin,P., Meer, B., Musonda, D., Perdue, D., Poisson, S. and Siebert, S. (1987). World agriculture and soil erosion. BioScience, 37(4), pp.277-283. Retrived from: https://www.jstor.org/stable/1310591

Piyathilake, I. D. U. H., Sumudumali, R. G. I., Udayakumara, E. P. N., Ranaweera, L. V., Jayawardana, J. M. C. K., \& Gunatilake, S. K. (2020). Modeling predictive assessment of soil erosion related hazards at the Uva province in Sri Lanka. Modeling Earth Systems and Environment, 1-16. DOI: https://doi.org/10.1007/s40808-020-00944-1

Prasannakumar, V., Vijith, H., Abinod, S. and Geetha, N.J.G.F. (2012). Estimation of soil erosion risk within a small mountainous sub-watershed in Kerala, India, using Revised Universal Soil Loss Equation (RUSLE) and geo-information technology. Geoscience frontiers, 3(2), pp.209-215. DOI: https://doi.org/10.1016/j.gsf.2011.11.003

Ranagalage, M., Estoque, R.C., Handayani, H.H., Zhang, X., Morimoto, T., Tadono, T. and Murayama, Y. (2018). Relation between urban volume and land surface temperature: A comparative study of planned and traditional cities in Japan. Sustainability, 10(7), p.2366. DOI: https://doi. org/10.3390/su10072366

Renard, K.G., Foster, G.R., Weesies, G., McCool, D., Yoder, D. (1997). Predicting soil erosion by water: a guide to conservation planning with the Revised Universal Soil Loss Equation (RUSLE) vol 703. United States Department of Agriculture Washington, USA. 
Renard, K.G., Foster, G.R., Weesies, G.A. and Porter, J.P. (1991). RUSLE: Revised universal soil loss equation. Journal of soil and Water Conservation, 46(1), pp.30-33. Retrived from: https://www. jswconline.org/content/46/1/30/tab-article-info

Roose, E. (1996). Land husbandry: components and strategy (Vol. 70). Rome: FAO. Retrived from:https://www.betuco.be/CA/Land\%20husbandry\%20\%20Components\%20and\%20 strategy\%20erosion\%20FAO.pdf

Senanayake, S., Pradhan, B., Huete, A. and Brennan, J. (2020). Assessing Soil Erosion Hazards Using Land-Use Change and Landslide Frequency Ratio Method: A Case Study of Sabaragamuwa Province, Sri Lanka. Remote Sensing, 12(9), p.1483. DOI: https://doi.org/10.3390/rs12091483

Senanayake, S.S., Munasinghe, M.A.K. and Wickramasinghe, W.M.A.D.B. (2013). Use of erosion hazard assessments for regional scale crop suitability mapping in the Uva Province. Annals of the Sri Lanka Department of Agriculture, 15, pp.127-141.

Sharma, A. (2010). Integrating terrain and vegetation indices for identifying potential soil erosion risk area. Geo-Spatial Information Science, 13(3), pp.201-209. DOI: https://doi.org/10.1007/ s11806-010-0342-6

Sharp R, Tallis, H.T., Ricketts, T., Guerry, A.D., Wood, S.A., Chaplin-Kramer, R., Nelson, E., Ennaanay,, D. W, S., Olwero, N., Vigerstol, K., Pennington, D., Mendoza, G., Aukema, J., Foster, J., Forrest, J., Cameron,, D. A, K., Lonsdorf, E., Kennedy, C., Verutes, G., Kim, C.K., Guannel, G., Papenfus, M., Toft, J., Marsik,, M. B, J., Griffin, R., Glowinski, K., Chaumont, N., Perelman, A., Lacayo, M. Mandle, L., Hamel, P., Vogl,, A.L. R, L., Bierbower, W., Denu, D., and Douglass, J. (2018). InVEST 3.7.0.post10+ug.h2ce175de3cea User's Guide The Natural Capital Project, Stanford University, University of Minnesota, The Nature Conservancy, and World Wildlife Fund.

Shi, Z.H., Fang, N.F., Wu, F.Z., Wang, L., Yue, B.J. and Wu, G.L. (2012). Soil erosion processes and sediment sorting associated with transport mechanisms on steep slopes. Journal of Hydrology, 454, pp.123-130. DOI: https://doi.org/10.1016/j.jhydrol.2012.06.004

Shougang, Z. and Ruishe, Q. (2014). The application and study of GIS in soil Erosion model. Advances in Sciences and Engineering, 6(2), pp.31-34.

Singh, G. and Panda, R.K. (2017). Grid-cell based assessment of soil erosion potential for identification of critical erosion prone areas using USLE, GIS and remote sensing: A case study in the Kapgari watershed, India. International Soil and Water Conservation Research, 5(3), pp.202-211. DOI: https://doi.org/10.1016/j.iswcr.2017.05.006

Smith, H.J. (1999). Application of empirical soil loss models in southern Africa: A review. South African Journal of Plant and Soil, 16(3), pp.158-163. DOI: https://doi.org/10.1080/02571862. 1999.10635003

Thuraisingham, K., Weerasinghe, V. (2009). Soil erosion study for Bibili Oya watershed in Kelani river basin. Retrived from: https://www.academia.edu/15786545/Soil_erosion_study_for_ Bibili_Oya_watershed_in_Kelani_river_basin

Udayakumara, E.P.N., Shrestha, R.P., Samarakoon, L. and Schmidt-Vogt, D. (2010). People's perception and socioeconomic determinants of soil erosion: A case study of Samanalawewa watershed, Sri Lanka. International journal of sediment research, 25(4), pp.323-339. DOI: https://doi.org/10.1016/S1001-6279(11)60001-2 
Udayakumara, E., Shrestha, R., Samarakoon, L., \& Schmidt-Vogt, D. (2012). Mitigating soil erosion through farm-level adoption of soil and water conservation measures in Samanalawewa Watershed, Sri Lanka. Acta Agriculturae Scandinavica, Section B-Soil \& Plant Science, 62(3), 273-285. DOI: https://doi.org/10.1080/09064710.2011.608708

Udayakumara, E.P.N. and Gunawardena, U.A.D.P. (2016). Reducing Siltation and Increasing Hydropower Generation from the Rantambe Reservoir, Sri Lanka (No. 111). Retrived from:http:// www.sandeeonline.org/uploads/documents/publication/1097_PUB_Working_Paper_No._11316.pdf

Weerasinghe, R., Jayawardana, J., and Udayakumara, E.P.N. (2016). Quantitative assessment of soil erosion and its association with river health in Uma Oya watershed in Sri Lanka ISAE 2016, pp.137-140.

Wickramasinghe A (1988) Impact of land use practices on environment conditions of the hill country of Sri Lanka Sri Lanka J Soc Sci 11, pp.95-113

Wickramasinghe, L.A. and Premalal, R. (1988). Development of a rainstorm erosivity map for Sri Lanka. In Proc of the $5 t$ h International Soil Conservation Conference. Ed. Sanam Rimwanich. Bangkok, Thailand.

Wijesekara, S. and Samarakoon, L. (2002). Application of a soil erosion model in a grid-based GIS environment. Asian J Geo Inf, 3(1), pp.49-54.

Wijesekera, S. and Samarakoon, L. (2001). November. Extraction of parameters and modelling soil erosion using GIS in a grid environment. In Asian Conference on Remote Sensing,(5-9 September), Singapore.

Wijesekera, N.T.S. and Chandrasena, K.G. (2001). Calibration of a GIS based Watershed Model to Identify Priority Zones for Soil Conservation. CD of Prric-settings of the Asia G15 '2001 S_vmp0.।" iurn. Center for Spatial Information Science, the University of Tokyo, Japan.

Wijesekera, S. and Samarakoon, L. (2001), November. Extraction of parameters and modelling soil erosion using GIS in a grid environment. In Asian Conference on Remote Sensing,(5-9 September), Singapore. Retrived from: https://pdfs.semanticscholar.org/ daa1/6b588ea295d48ad11f6ec15b79bcab4c8993.pdf

Wijesundara, N.C., Abeysingha, N.S. and Dissanayake, D.M.S.L.B. (2018). GIS-based soil loss estimation using RUSLE model: A case of Kirindi Oya river basin, Sri Lanka. Modeling Earth Systems and Environment, 4(1), pp.251-262. DOI: https://doi.org/10.1007/s40808-018-0419-z

Wilson, J.P. and Gallant, J.C. eds. (2000). Terrain analysis: principles and applications. John Wiley $\&$ Sons.

Wischmeier, W.H. and Smith, D.D. (1965). Predicting rainfall-erosion losses from cropland east of the Rocky Mountains: Guide for selection of practices for soil and water conservation (No. 282). US Department of Agriculture.

Wischmeier, W.H. and Smith, D.D. (1978). Predicting rainfall erosion losses: a guide to conservation planning (No. 537). Department of Agriculture, Science and Education Administration.

Yitayew, M., Pokrzywka, S.J. and Renard, K.G. (1999). Using GIS for facilitating erosion estimation. Applied Engineering in Agriculture, 15(4), p.295. Retrived from: https://elibrary. asabe. org/abstract.asp?aid $=5780$ 
Zachar, D. (2008). Chapter 3 Problems and Methods of Soil Erosion Research. Developments in Soil Science (10). pp.137-203. DOI: https://doi.org/10.1016/S0166-2481(08)70646-9

Zijister, P.J. (1989). Erosion hazard and land suitability in Nuwara Eliya district. Integrated Rural Development Project, Sri Lanka. 